\title{
ESTIMATION OF FLUORIDE GONGENTRATION IN DRINKING WATER OF KATHMANDU VALLEY
}

\author{
Shah P, Khanal S
}

Department of Pedodontics and Preventive Dentistry, Nepal Medical College Teaching Hospital, Attarkhel, Gokarneshwor-8, Kathmandu, Nepal

\begin{abstract}
Fluoride has a preventive effect on dental caries. However, excessive/insufficient ingestion of fluoride can lead to the development of dental fluorosis/increased risk for dental caries respectively. The objective of this study was to estimate fluoride concentration in drinking water of Kathmandu valley. It was a community based cross-sectional study in which drinking water samples were collected from municipal water supply and bottled water. Municipal water supply was collected according to eight water schemes in Kathmandu valley and as for bottled water, 35 samples were randomly collected according to different brand names available in the commercial market. The samples were analyzed for fluoride content by SPADNS colorimetric method as per standard procedure set by American Public Health Association (APHA 2012).The results revealed that the fluoride content in drinking water samples was below the permissible limit $(<0.5 \mathrm{ppm})$ as per Nepal's drinking water quality standards and WHO guidelines. Hence, implementation of water fluoridation program can be initiated for municipal water supply and bottled water for prevention of dental caries to optimize the oral health of people.
\end{abstract}

\section{KEYWORDS}

Fluoride, dental fluorosis, dental caries, drinking water

\section{CORRESPONDING AUTHOR}

Dr. Priyanka Shah

Lecturer,

Department of Pedodontics and Preventive Dentistry,

Nepal Medical College, Attarkhel, Gokarneshwor-8,

Kathmandu, Nepal.

Email: picu.shah@gmail.com

Orcid ID: 0000-0003-3167-0595

DOI: https://doi.org/10.3126/nmcj.v22i1-2.30031 


\section{INTRODUCTION}

Fluoride, a natural element, is found at varying concentrations in all drinking water. ${ }^{1}$ World Health Organization has considered fluoride as one of the very few chemicals that have been shown to cause significant effect on people's health through drinking water. There is a thin line between the desired and adverse doses of fluoride. ${ }^{2}$ Fluorides have been recognized as an effective means for the prevention of dental caries. Though fluoride enters the body through food, water, industrial exposure, drugs, cosmetics, etc., drinking water is the major contributor (75-90\% of daily intake). ${ }^{3}$ A limit value of $1.5 \mathrm{mg} / \mathrm{L}$ has been set by WHO for fluoride in drinking water. ${ }^{4}$ The major health issues caused by fluoride when it is exceeding the limit value are dental fluorosis, teeth mottling, skeletal fluorosis and deformation of bones in children as well as in adults. ${ }^{5,6}$ Approximately 62 million people including 6 million children suffer from fluorosis. ${ }^{7,8}$

Most of the countries suffering from fluoride health problems are located in hot climate zone and belong to the third world. ${ }^{9}$ Classic studies conducted by Dean established the qualitative relationship between fluoride content in drinking water and the occurrence of dental fluorosis. ${ }^{10}$ Even though extensive studies have been conducted, there seems to be no effective cure for these diseases.

Research on oral health effects of fluoride have shown caries preventive effect in drinking water. ${ }^{11}$ International studies support the widely held view that the majority of bottled waters available contain negligible fluoride in terms of its dental health benefits. ${ }^{12,13,14}$ Therefore, it is desirable to drink water having a fluoride concentration less than certain value. Hence, drinking water with fluoride concentration (cf) $>1.5 \mathrm{mg} / \mathrm{l}$ needs treatment (WHO 1994). This information would be very useful in planning and implementation of oral health primary prevention programs in future.

Kathmandu valley constitutes the country's single largest urban economy and has a population of 1.5 million. ${ }^{15}$ People residing in this valley are slowly opting for jar water in their household for drinking purposes. But research on the level of fluoride in bottled water and tap water is inadequate. Hence, this study was undertaken

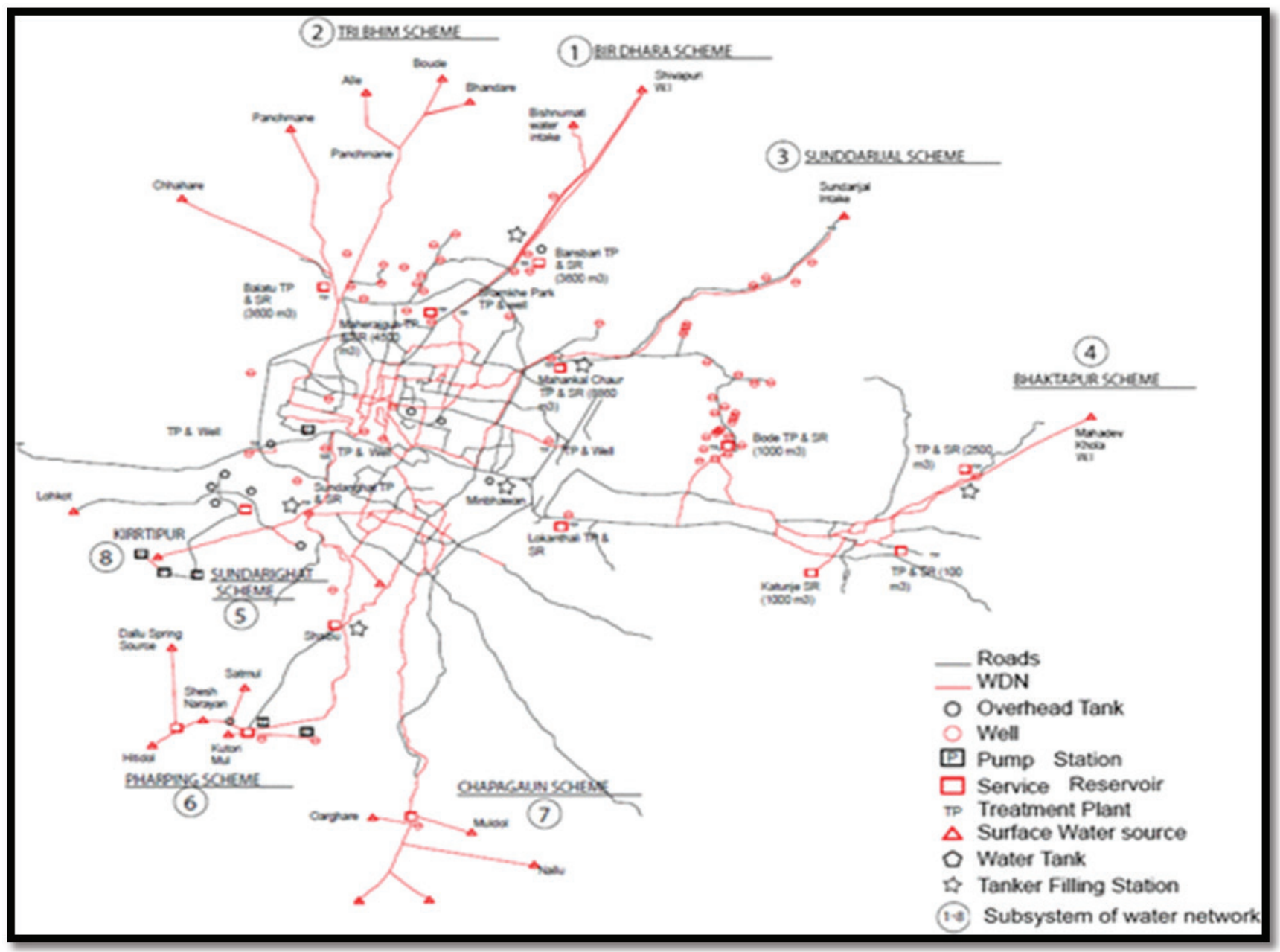

Fig. 1: Eight water schemes in Kathmandu Valley 
owing to the sparse information on the subject of fluoride level in drinking water in Kathmandu Valley, the objective of which was to estimate fluoride concentration in drinking water of Kathmandu Valley.

\section{MATERIALS AND METHODS}

The study was a community based cross-sectional survey done in the time period between April to July 2019.

\section{Sample collection:}

Source of municipal water samples:

There are 8 schemes in Kathmandu Valley for the collection of surface water source (Fig. 1). These are:

1. Bir dhaara scheme

2. Tri-Bhim scheme

3. Sundarijal scheme

4. Bhaktapur scheme

5. Sundarighat scheme

6. Pharping scheme

7. Chapagaun scheme

8. Kirtipur scheme

Three samples (total $n=24$ ) from each of these schemes was collected considering the distribution pattern of each scheme.

Source of bottled water samples: For the bottled water, 35 samples manufactured in Kathmandu Valley were randomly selected.

Collection and analysis of samples: The water samples was collected in good quality $125 \mathrm{ml}$ sterilized polyethylene bottles without addition of any preservative and was identified with labels indicating the location of the collection site and date. The sampleswere stored at room temperature till the analysis. The samples were pre-coded and were not disclosed to the technician so as to eliminate any potential bias. The fluoride content in drinking water was analyzed by Environment and Public Health Organization (EPHO) located in Baneshwor by SPADNS colorimetric method as per standard procedure set by American Public Health Association (APHA 2012).

\section{Fluoride Estimation:}

Principle (SPADNS colorimetric method): The SPADNS colorimetric method is based on the reaction between fluoride and a zirconiumdye lake. Fluoride reacts with the dye lake, dissociating a portion of it into a colorless complex anion $\left(\mathrm{ZrF}_{6}{ }^{2-}\right)$ and the dye. As the amount of fluoride increases, the color produced becomes progressively lighter. ${ }^{16}$

Materials used:

Colorimetric equipment: Spectrophotometer, Filter photometer
Reagents used: Standard fluoride solution, SPADNS solution, zirconyl-acid reagent, acid zirconyl-SPADNS reagent, reference solution, sodium arsenite solution. ${ }^{16}$

\section{Ethical consideration:}

Ethical approval was obtained from Institutional Review Committee of Nepal Medical College (NMC_IRC reference number 006-075/076).

Table 1: Fluoride concentration of water in

Kathmandu Valley according to different water schemes

\begin{tabular}{|llc|} 
S.N. $\begin{array}{l}\text { Water Schemes } \\
\text { (Municipal water } \\
\text { supply) }\end{array}$ & $\begin{array}{l}\text { Fluoride } \\
\text { concen- } \\
\text { tration } \\
(\mathrm{mg} / \mathrm{l})\end{array}$ & $\begin{array}{c}\text { WHO } \\
\text { standard } \\
\text { guideline } \\
\text { values }\end{array}$ \\
\hline
\end{tabular}

1. Birdhaara scheme

S1 $<0.5$

S2 $<0.5$

S3 $0.59^{*}$

2. Tri Bhim Dhaara

scheme

S1

$<0.5$

S2 $<0.5$

S3 $<0.5$

3. Sundarijal scheme

S1

$<0.5$

S2

$<0.5$

S3

$<0.5$

4. Bhaktapur scheme

S1

$<0.5$

S2

S3

5. Sundarighat

scheme

S1

S2

$<0.5$

$<0.5$

$0.5-1.5$ $\mathrm{mg} / \mathrm{l}$

$<0.5$

$<0.5$

$<0.5$

6. Pharping scheme

S1

$<0.5$

S2

$<0.5$

S3

$<0.5$

7. Chapagaun

scheme

S1

$<0.5$

S2

$<0.5$

S3

$<0.5$

8. Kirtipur scheme

S1

$<0.5$

S2

$<0.5$

S3

$<0.5$

$\begin{array}{ll}\text { S1 } & <0.5 \\ \text { S2 } & <0.5 \\ \text { S3 } & <0.5\end{array}$




\section{RESULTS}

A total of 59 samples of water were collected, among which 24 was municipal water supply and 35 was bottled water. Among 59 samples, only 1 (1.6\%) from municipal water sample had Fluoride level of $0.59 \mathrm{ppm}$ whereas the other entire sample (98.3\%) including bottled water had Fluoride level of $<0.5$ ppm (Table 1 ).

\section{DISCUSSION}

An excessive level of fluoride leads to various health issues, mostly on dental and skeletal fluorosis which often leads to vulnerabilities in the bones and teeth. At optimum concentrations, fluoride is beneficial to the teeth, mostly in helping eliminate dental caries; admittedly, it also does decontaminate water as it kills various bacteria which may be present there. ${ }^{17}$ Occurrence of fluoride in drinking water has been widely reported in literature from various studies. ${ }^{18}$ Therefore it was necessary to carry out a survey in Kathmandu Valley, in order to determine the current level of fluoride in drinking water.

The fluoride concentration in the municipal water supply and bottled water of Kathmandu Valley in this study was $<0.5 \mathrm{ppm}$. This result was in agreement with the previous study conducted in Eastern region of Nepal. ${ }^{19}$ Similar results were also obtained in a study done in Nepalese school children population, according to this study in most districts, the fluoride level was low; exceeding $0.8 \mathrm{ppm}$ only in one district (Parsa), and only $4 \%$ of the study population was exposed to the optimal level of fluoride in drinking water. This study also revealed those living in the Eastern and Tarai regions and in urban locations had a significantly higher degree of fluorosis than children living in the other regions. ${ }^{20}$

In contradiction, a study done in 2011 to assess the quality of ground water in the Kathmandu Valley disclosed fluoride and hardness concentrations in agreement with the recommendations of WHO drinking-water quality guidelines, however the water was vulnerable to drink due to presence of iron and coliform bacteria. ${ }^{21}$ In many studies world over, similar results has been observed that high concentrations of fluoride occur naturally in groundwater, which is the main source of drinking water. Undeniably, fluoride is one of the most abundant elements in the earth and it generally infiltrates groundwater by natural processes. ${ }^{17}$

Fluoride concentration of bottled water in our study was also below optimum. Moreover, none of the packaged bottle water had fluoride concentration in their product label. This result was similar with a study done in bottled water in Mathura City and Faridabad City in India. ${ }^{22,23} \mathrm{~A}$ study done in Chennai also had less than optimal fluoride content in bottled water and there was a significant variation in fluoride concentration of each brand and among different batches of same brand bottled waters. ${ }^{24}$ In another study done by Armfield et al, has clearly shown that the consumption of non-public water (bottled water and rainwater tanks) may put the children at increased risk of developing caries. ${ }^{25}$ So, the importance of consumption of fluoride in optimal amount is very essential for a better dental health for children.

This study concluded that most of the drinking water samples collected from Kathmandu Valley had fluoride concentration below the WHO recommended guidelines. In conclusion, the present study highlights the need for water fluoridation, school water fluoridation, professional fluoride application and use of fluoridated dentifrices. It requires incessant efforts and coordination of public health planners, administrators and authorities to make the fluoride in drinking water optimum for public health consumption. Fluoridation of water should be prioritized before distribution to reduce the risk for dental caries and optimum oral-health benefits.

\section{ACKNOWLEDGEMENTS}

Authors would like to acknowledge Nepal Medical College for the research grant and Dr. Jemish Acharya, Doctor of Public Health Scholar Department of Global Heath, Mahidol University, Bangkok, Thailand for her help.

\section{REFERENCES:}

1. Winston A, Bhaskar A. Caries prevention in the 21st century. J A Dent Assoc 1998; 129: 1579-87.

2. Czarnowski W, Wrzesniowska K, Krechniak J. Fluoride in drinking water and human urine in Northern and Central Poland. Sci Total Environ 1996; 191: 177-84.

3. Saralakumari D, Rao PR. Endemic fluorosis in the village Ralla Anantapuram in Andhra Pradesh: An epidemiological study. Fluoride 1993; 26: 177-80.

4. World Health Organisation. Fluoride in Drinkingwater Back ground Document. Guidelines for Drinking Water Quality 2006; 1-9.

5. Sunitha V, Reddy B, Srinivas B. Fluoride in ground water of Anantapur town, Anantapur District, Andhra Pradesh, India. J Appl Geochem 2004; 6: 368-72. 
6. Chan JT, Stark C, Jeske AH. Fluoride content of bottled waters: implications for dietary fluoride supplementation. Tex Dent J 1990; 107: 17-21.

7. Garg M, VK K, Malik R. Ground- water quality in some villages of Haryana, India: focus on fluoride and fluorosis. J Hazard Mater 2004; 106: 85-97.

8. Singh K. National scenario of fluorosis: The visible villain. Indian J Environ Prot 2007; 27: 740-50.

9. Barghouthi Z, Amereih S. Field method for estimation of fluoride in drinking groundwater by photometric measurement of spot on aluminium quinalizarin reagent paper. Arab J Chem 2017; 10: 2919-25.

10. Pagaria S, Lodha R, Dubey A, Avinash A, Baranwal $\mathrm{R}$ MS. Fluoride Estimation in Drinking Water and Its Correlation With Severity of Dental Fluorosis Among 12 -15 Year School Children of 3 Districts of Correlation With Severity of Dental Fluorosis. Int'l J Med Appl Sci 2016; 4: 58-70.

11. Petersen P, Lennon M. Effective use of fluorides for the prevention of dental caries in the 21st century: The WHO approach. Community Dent Oral Epidemiol. Community Dent Oral Epidemiol 2004; 32: 319-21.

12. Weinberger SJ. Bottled drinking waters: are the fluoride concentrations shown on the labels accurate? Int'l J Paediatr Dent 1991; 1: 143-6.

13. Lalumandier J, Ayers L. Fluoride and bacterial content of bottled water vs tap water. Arch Fam Med 2000; 9: 246-50.

14. Walia T, Abu Fanas S, Akbar M, et al. Estimation of fluoride concentration in drinking water and common beverages in United Arab Emirates (UAE). Saudi Dent J 2017; 29: 117-22.

15. Koju NK, Prasai T, Shrestha SM, et al. Drinking Water Quality of Kathmandu Valley. Nepal J Sci Technol 2015; 15: 115-20.
16. Rice EW, Baird RB, Eaton AE et al. Standard Methods For the Examination of waste and water. 22nd ed. Colorado: American water works Association; 2012.

17. Bashir MT, Ali SB, Adris A et al. Health effects associated with fluoridated water sources-a review of Central Asia. Asian J Water, Environ Pollut 2013; 10: 29-37.

18. Brindha K, Elango L. Fluoride in Groundwater: Causes, Implications and Mitigation Measures. Fluoride Prop Appl Environ Mgmt 2011; 111-36.

19. Singh A, Shrestha A, Bhagat T. Fluoride level in drinking water sources of Eastern Nepal. J Nepal Health Res Counc 2019; 16: 414-8.

20. Karki S, Laitala M, Humagain M, et al. Oral health status associated with sociodemographic factors of Nepalese schoolchildren: a population-based study. Int'l J Dent 2018; 68: 348-58.

21. Pant BR. Ground water quality in the Kathmandu valley of Nepal. Environ Monit Assess 2011; 178: 477-85.

22. Bhalla M, Na I, Kaur N et al. Estimation of Fluoride Concentration in Municipal Water Supply and Commercially Available Packaged Drinking Water in Mathura City. A -Comparative Study. J Oral Heal Com Dent 2014; 8: 131-4.

23. Dhingra S, Marya CM, Jnaneswar A et al. Fluoride concentration in community water and bottled drinking water: A dilemma today. Kathmandu Univ Med J 2013; 11: 117-20.

24. Somasundaram S. Fluoride Content of Bottled Drinking Water in Chennai, Tamilnadu. J Clin Diagn Res 2015; 9: 32-4.

25. Armfield J. Community effectiveness of public water fluoridation in reducing children's dental disease. Public Heal Rep 2010; 125: 655-64. 